\title{
Rhetorical Analysis of Stand-Up Comedy: A Case Study of Indonesian and Canadian Comedians
}

\author{
R M Panjaitan, R R Simanjuntak \\ English Department, Faculty of Humanities, Bina Nusantara University, Jakarta, Indonesia \\ *Corresponding author email: david.panjaitan001@binus.ac.id
}

\begin{abstract}
This paper focuses on analysing the aspect of rhetoric between Women Overthink, Men Underthink, Russell Peters and Cowok Pasti Bohong, Tentang Cowok dan Cewek, Raditya Dika. The purpose of the analysis is to find the aspects of rhetoric are used by a script. This paper applies qualitative research and exposition methods, by analyzing, classifying and comparison the script using Robert and Warren's rhetorical theory and Greene's persuasion in stand-up comedy theory. Based on the findings of this research, it is concluded that style, Raditya Dika's and Russel Peters's script is irony tones to compare the habits and characters of men and women using informal as casual conversations with good friends. Diction, Raditya Dika's script is abstract then concrete and denotation meaning. Meanwhile, Russell Peters and Raditya Dika's scripts are specific, then an abstract and denotation meaning. Metaphor, Raditya Dika's script is Half-dead Metaphor. Meanwhile, the Russell Peters script is not finding a metaphor. The implication of this research is to introduce rhetorical analysis into stand-up comedy content.
\end{abstract}

Keywords: Stand-Up Comedy, Indonesian, Canadian Comedians

\section{INTRODUCTION}

In 1979, the first comedy club was founded, the Comedy Store opened in London by Peter Rosengard. The current British comedy circuit emerges from the ' alternate ' comedy Revolution of the year 1980, with politics and humour observations becoming a prominent style for development [1]. While Indonesia stand-up comedy appeared in the year 2000 through stand-up comedy community.

Comedian creates a script that has a purpose to make the audience laugh. Stand-up comedy also intends to make a comedy from the script. In this case, the language styles used directly help the comedian script. Comedians make the script by choosing the language style to be a paragraph that has the main idea. The language is analysed in a certain context to get the exact meaning that the speaker or addresser intended. This makes the language used in a particular context seen as a social practice [2]. No matter how clever the rhetor is, the result is strategically influenced by fact, reasoning, ethos, pathos, value, structure or organization, style/language, and such [3].

In the context of stand-up comedy, Discipline writes, performs and Perfects stand-up comedy in accordance with rhetoric descriptions. Rhetoric is an important and not only natural art; it should be studied and practiced as it should be any discipline that deserves to be taken seriously [4].

Comedy is used for rhetoric to convey their thoughts, feelings, and intentions about humouring the audience. If comedians from different countries create the same material, what about the rhetoric they use? Therefore, the rhetoric of this analysis took the example of two comedians with different languages anyway through what they said and how they said it. The comedy against the rhetoric used by comedian Russell Peters from Canada in the title "Women overthink, Men underthink" and comedian Raditya Dika from Indonesia in the title "guys must be lying" and "about guys and girls".

Russell Peters and Raditya Dika talk about different women from men. The audience likes the material though in everyday, women have the dominant impression, but this makes the audience laugh. Is the truth told about anxiety gives a sense of humor or rhetoric supporter used by Russell Peters and Raditya Dika who made the audience laugh?

Therefore, the author decides to investigate two comedians Russell Peter and Raditya Dika to the audience on the stage comedy on the same topic about the genre.

This understanding cannot be achieved without prior research on the key aspects of rhetoric and persuasion required for Stand-Up Comedy. To achieve this analysis, this study discusses the theories received in the field of rhetoric. With this theoretical knowledge, the study continues to discuss how each of these theories work in the world of stand-up comedy and how Rhetoric and comedy [2].

This paper focuses on analysing the aspect of rhetoric between "Women Overthink, Men Underthink", Russell Peters and "Cowok Pasti Bohong”, "Tentang Cowok dan Cewek", Raditya 
Dika. The purpose of the analysis is to find the aspects of rhetoric is used by the script. There are two questions navigating the study, which are (1) what are the aspects of Modern Rhetoric used to compose the scripts? and (2) what are the similarities and differences found between the stand-up comedians when applying these rhetorical aspects?

\section{PREVIOUS STUDIES}

Modern rhetoric centers on paragraphs and sentences, diction, metaphors, tones and other aspects of style $[3,4]$. In the formulation, the author only discusses three aspects which constitute a unity in the literary and linguistic sections, namely aspects of style, diction and metaphors.

To make a joke at the expense of a friend just to please her own vanity in her wit and in doing so loses a friend. The reason should serve to show us the way to long-run satisfaction; but sometimes, human nature being what it is, people have to appeal to short-range satisfactions in order to lead someone to see the long- range satisfaction. It has to make a person feel that the immediate effort is worthwhile. Our problem is to find the way to establish fruitful contact with him. That is the problem of persuasion in argument [3].

When modern rhetoric was finally published, this intense attention to style resulted primarily in lengthy (and at times quite theoretical and abstract) discussions of style, combined with abundant exercises as Warren had suggested. Students are instructed to not only compare and describe particular styles and tones but to practice shaping sample selections of their writing (or their imitations of others' style and structure via their own content) to explore a range of stylistic and tonal possibilities. Students are asked to think a good deal about how style can shape an essay and pinpoint on the level of the sentence and beyond how particular stylistic and rhetorical effects are achieved. The textbook's apparatus regularly entreats students to both pay attention to particular stylistic problems or choices and reflect on the larger implications of style in communication [4]. Most important, imagery through style sets the picture of things in action for an audience or captures an idea in a striking and fascinating way.

The use of current terms, everyday language, is an important component of style. Aristotle endorsed the use of self-deprecatory remarks to project a sense of humility or humour [5].

Some words in English, it is true, particularly scientific words, do represent the only name to have for a specific object or substance. Lem ming, for example, is the only name to have for a certain mouse-like rodent; purine is the only name of a compound the chemical formula of which is C5H4N4. The language of science ideally is a language of pure denotation. But this constitutes a special case, and its problems are different from those of more ordinary languagee [3].

There are two kinds of the metaphor terms. First, the term "dead metaphor" can itself illuminate the problem now being considered. With "dead" metaphors, people can say, rigor mortis has set in: they have no flexibility, no force; they have stiffened into one meaning. Second, metaphors that are still alive prove that they are alive by their flexibility; and because they are still alive, they can be used to give colour and life to a piece of writing. They are concrete and particular; they reflect the world of the senses. They can still excite the imagination. [3].

\section{RESEARCH METHODS}

Data gathered from scripts and authors watched three videos on YouTube. The script was taken to be analyzed on modern rhetoric and persuasive means as a rhetorical aspect. An indirect observation was made by watching videos on YouTube to collect data from two comedians, Russel Peters and Raditya Dika.

There were two procedures for analysing the scripts.

First, the analysis was focused on the use of style. This can be applied to anything that can be regarded as having a part. Analysis can be regarded as a description of a matter by distinguishing its parts. This kind of description, which we will now contrast with the usual description, is called a technical (or expository) description. It can compare the technical descriptions and regular descriptions by considering the different types of opportunities from where they appear.

Technical descriptions arise from requests for information about the things described. This was done by observing the request to a direct impression sense of things, is explained. The first type of description is expository that it tries to enlarge the understanding. The second type, the usual description, aims to give us an experience of the object through imagination. It called a suggestive description. The script is analysed by exploring aspects of modern rhetoric. The analysis focused on the analysis of the three aspects of modern rhetoric used in the script. It is an aspect of style, diction, and metaphor.

Second was comparative analysis. This analysis focuses on indicating similarities between two or 
more things. Contrast, by indicating the difference. Comparison was done on scripted data which had been classified earlier.

Moreover, the persuasive rhetorical tool to be applied is focused on text, writers, objectives, and

The steps in conducting this research could be seen below in Figure1:

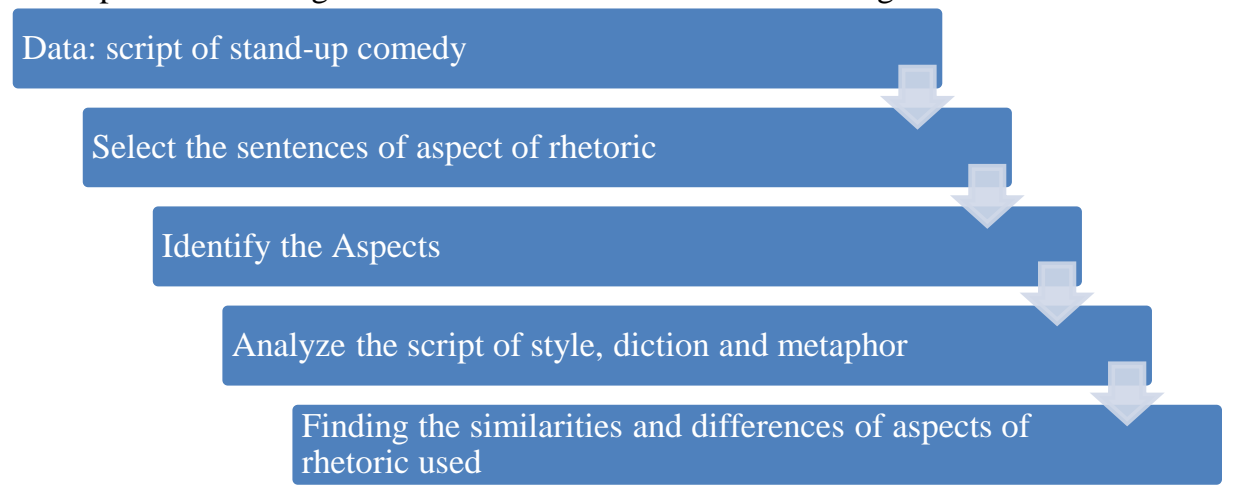

FIGURE 1 Research Procedure simultaneously. arrangements of ideas. All aspects can be depicted simultaneously, this research should be concluded. Therefore, the discussion can be depicted

\section{RESULTS AND DISCUSSION}

There are two discussion topics are analysed by the author. First is an aspect of rhetoric used by both stand-up comedies. Second, the similarities and differences from the aspects of rhetoric used by comedians are presented.

In this section, the author attempts to discuss the comparison of rhetorical elements in Stand-Up Comedy by two comedians in both Indonesian and English. Currently, the author only takes 3 videos consisting of "Tentang Cowok dan Cewek", "Cowok Pasti Bohong" by Raditya Dika and "Women overthink, Men underthink" by Russell Peters with the same topic and duration.

In addition, the authors analyzed the rhetoric based on Brooks and Warren's theory in his book titled "Modern Rhetoric (second edition)", as well as written in the journal Tara Lockhart as well. Center of rhetoric theory of modern elements such as: style, diction, and metaphor. In addition, the author takes a boundary of findings that only discusses the modern rhetoric elements in stand-up comedy based on the results of analysis. The study did not want to measure the quality of comedy viewers by both comics.

\subsection{Style}

An example for the use of style could be seen from the example below:

$$
\text { RD: Eh lo bisa ga minum Pertamax? Ga bisa }
$$

\section{right?}

Can you drink Pertamax? I don't think so,

The word "Pertamax" refers to fuel. The style used in this excerpt was rhetorical question, in which the audience does not need to answer and does not need answers. Even the meaning of a rhetorical question a little bit awkward can be so equipped with Raditya Dika voice tone that is a little serious.

On the other hand, Russell Peters used a different style, which was irony statement. This refers to some excerpt, while Exaggerating statements are found in some excerpt. Slang word like "we" as if he were in a conversation with a good friend. It has a tone informality reflecting the easy attitude towards Rusell Peters and the audience. This is a general consideration with regard to the first typestyle, in the first place, the style is never considered as a veneer, the decorated surface is put on top of the content.

Raditya Dika and Russell Peters are comedians who always style their entire contents. However, a good style is always impressed with their personality. As an example of an excerpt of RP: 2 on aspects of style:

"I had a weird dream" I wake up and go. I wish I could remember my dreams.

The tone as a qualification of the ironic statement, the word "Wish" used by Russell Peters means a sense of taste or revealing something that could not or might not have happened. When her boyfriend tells her about her dream, it turns out she doesn't even remember her own dream. Nada as a qualifying girlfriend Attitude "I wish I could recall my dreams" is the attitude of her boyfriend (Russell Peters) who 
doesn't care about it done by describing her style and tone.

They convey the similarity of style as "tone of voice" to convey the word and not confuse the audience. Tone as an expression of comedian attitude is their personality. Tone as a qualification of irony and exaggeration if meaning is also equal to their script.

\subsection{Diction}

According to Brooks and Warren theory, diction has been divided into main meanings (dentations) and implied meanings (connotations), general, specific, abstract, and concrete words. The main meaning (denotation) of words is the definition of naked diction said. The meaning of the word implied (connotations) includes all the emotional tones suggested by the word. A common word refers to a group or class. Specific refers to the member of the class. A concrete word has an object as a referral, other than the real ones for our five senses. Abstract has a concept, signifying ideas, emotions, intangible conditions as a referral. After analyzing the types of diction in Raditya Dika and Russell Peters, the author finds that the six types of diction are used by comedians. It is denotation, connotations, general, specific, abstract, and concrete words. The audience had been attracted to the diction that comedians made it. Comedians can choose the right words by analyzing the diction first, so delivering the word on the stage doesn't mute the audience.

Some chart will explain the diction in Raditya Dika He prefers abstract diction (adjectives or feelings, then followed by other types of diction. As an example, excerpt of RD: 1a on diction:

"Cewek itu imajinatif banget, suka berkreasi dengan angan- angan kalian sendiri'"

Explanation: The informal language used as the word girl and has the meaning of women (girls) and very (really). Advisories the word "wanita" specific is visit conversation. An abstract word is the word "angan-angan" which means a form that thinks about something. Finally, denotative is the word "you" referring to women. Explanation: The informal language used as a girl said and really has the meaning of women (girls) and very (really). While the specific word "wanita" is a conversation object. An abstract word is the word "angan-angan" means a form that thinks about something. Finally, denotative is the word "you" referring to women.

Meanwhile, the chart explains the volume of diction in Russell Peter's script. He prefers certain diction then followed by abstract diction. For example, excerpt of RP: 6 on diction: "a month into a relationship, a woman will Look at you and go, promise me something" "promise, you'll never lie to me"

"I Promise"

"and that's the first time."

Explanation: The specific word "a month into a relationship" refers to the length of time that relationship then Russell gives a statement about the behavior of women who want an appointment. Meanwhile, the abstract word "wish" which refers to sincerity to obey something, her boyfriend wants Russell to never lie to him. Finally, the specific word "we lie to you" refers to humans because Russell is a man and man has to lie.

\subsection{Metaphor}

Apparently in the context of a stand-up comedy metaphor not overused, it is not rich with metaphors but more concerned with persuasion tools to convey words and messages. In addition, the metaphor in Raditya Dika script refers to a half-dead metaphor. As an Excerpt of RD:

"tuh biasanya cewe cantik jalan di depan terus cowonya di belakang bawain tasnya dia

udah seperti budak tau nggak dia megangin tasnya dia."

Description: This is part of an element of similarity in a good metaphor, "budak" that refers to a boyfriend who always carries a boyfriend's bag. This comparison is not so much physical recovery as an association: Budak associations with characters, with positions and lifestyles.

Therefore, there is no more difference between the scripts Russell Peters and Raditya Dika. The impilation that makes the metaphor is useless in Russell's script is the stand-up character he has.

\subsection{Persuasion as a rhetoric tool}

The goal of a comedian is to make the audience laugh by making the audience want to listen to them. Based on a journal created by Grace F. Greene that explains how stand-up comedy is as a persuasive tool of rhetoric. Persuasion aims to convince, appeal to emotions, and the right way can make viewers willing to hear, to listen with sympathy, to benefit from doubt.

Raditya Dika has the right way to convince the audience by providing evidence to give attention that there is a motion illustration, and a conversation that sounds real. As an example, on the excerpt Raditya Dika:

Happening

(Excerpt RD:1A): cewek itu imajinasi banget, Ini bukti kalian kalau lebih pintar dari cowok 
(Excerpt RD:2A): gue pernah ya jemput cewe gue di rumahnya.

cewe gue masuk mobil nih

ga ngomong apa-apa

cuma nglihat gue sambil mukul gue

apa lagi ini? dosa apa lagi sayang?

(Excerpt RD:5A); dan (Excerpt RD:12A).

Iluration gestures

(Excerpt RD:2A).

(Excerpt RD:5A):

gue pernah mimpi pacaran sama dian sastro

tapi nggak juga gue ketemu Sastro gue bilang makasih buat kemarin malam, kan nggak juga kan

(Excerpt RD:7A):

kalian lihat deh di mall ciputra atau di plaza indonesia

tuh biasanya cewe cantik jalan di depan terus cowonya di belakang bawain tasnya dia

udah seperti budak tau nggak dia megangin tasnya dia.

(Excerpt RD:10A):

aku jadi alay gini nih ahhhhhh

(Excerpt RD:3B): 'enggak!'

'jangan bohong!'

Dia bilang gitu

Padahal kosong!

(Excerpt RD:5B); (Excerpt RD:8B); dan (Excerpt RD:9B).

Real sounding

Excerpt (RD: 5A); excerpt (RD: 6A); and excerpt (RD: 8A).

Russell Peters has the right way to convince the audience by giving a real-sounding conversation, this is the same tool persuasion in Raditya's script titled "cowok pasti bohong". They make a persuasion at the beginning of the topic and go to new topics, so the audience understands and follows the ideas expressed by comedians. For example, Russell Peters excerpts:

Conversations

(Excerpt RP: 2): "I had a weird dream" I wake up and go. I wish I could remember my dreams.

(Excerpt RP: 5): "What do you thinking about? " the And we tell you what we're thinking about nothing. (Excerpt RP: 6): A month into a relationship, a woman will

Look at you and go, "promise me something"

"promise, you'll never lie to me"

"I Promise"

And that's the first time we lie to you.

(Excerpt RP: 7): (Excerpt RP: 8): (Excerpt RP: 9): and (Excerpt RP: 10)

Comedians make a persuasion at the beginning of the topic and go to new topics, so the audience understands and follows the ideas expressed by comedians.

\section{CONCLUSION AND IMPLICATION}

The modern aspect of rhetoric is style, diction, and metaphor. According to Robert P Warren's theory, the tone style makes it easier for comedians to convey the word and not confuse the audience. Style is also a personality impression. Raditya Dika and Russell are famous comedians. They use a tone of irony to compare the habits and characters of men and women. Both scripts on the tone of irony have been analyzed capable of describing the differences between men and women so that the script is rich against punchlines (the audience can accept the word delivered and be laughed). On the same topic, they are comedy by using informal as a relaxing conversation with good friends. They both have their own style as comedians such as pretend face shapes and hand movements.

Diction of two scripts of comedians. According to the theory of Robert P Warren, there are three types of diction in general, the Denotation and connotations; General and specific; and abstract and specific. A variation of diction is formal, daily, and illiterate literature that most words are not completely denotative. Raditya Dika and Russell Peters also added some types of diction in their scripts. Raditya Dika Script applies the Indonesian language which is mostly an abstract type (25\%) (adjectives or feelings) then as a reference are diction concrete $(23 \%)$ and denotation. Meanwhile, Russell Peters applied the English language to most of the diction (32\%), followed by abstract diction (22\%) (which involves adjectives or feelings) and denotation.

The metaphor of both comedians. According to Robert P Warren's theory, the metaphor as an illustration and an important statement that has 3 metaphorical components including slang, jargon and confused metaphors and half-dead metaphors. In the case of Stand-up comedy by Raditya Dika, a Half-Dead metaphor (a word metaphor that does not contrast) is found so somewhat confusing to classify into a type of metaphor. While the script Russell Peters did not find a metaphor. Both comedians place more emphasis on diction and style. As Robert P. Warren remarks that the style represents "how" a thing is said, and how to determine something is said. Sentence structure, diction, and metaphors are just a few of those involved.

After classifying aspects of rhetorical it can be found the similarities and differences from the 
aspects of rhetoric. It found the script Raditya Dika has the aspect of metaphor while Russel Peter prioritizes diction and aspect of style. The script Raditya Dika has the word abstract (25\%) (adjectives or feelings) while the script Russell Peter has the specific word. The similarities in the rhetorical aspects found in the Russel and Raditya texts are in the style aspect. where they both use an ironical statement as a tone to express their script. Additional research to unite rhetoric with stand-up comedy context is Grace F Research stated that the persuasion tool in the rhetoric was applied by comedians. Raditya Dika and Russell Peters used persuasion at the beginning of the topic and headed to a new topic, so the audience understood and followed the ideas expressed by comedians.

The implication of this research is to introduce rhetorical analysis to stand-up comedy content. therefore, the problem formulation that will be proven is the rhetorical aspect of the script to assist comedians in making scripts with rhetoric.

\section{REFERENCES}

[1] Ihlen, O., \& Heath, R. L. 2019. Ethical grounds for public relations as organizational rhetoric. Public Relation Review(45), 101-824. Retrieved from www.elsevier.com/locate/pubrev

[2] Greene, G. F. 2012. Rhetoric in Comedy: How Comedians Use Persuasion and How Society Uses Comedians. The Corinthian, 13(11), 134-154. Retrieved from http://kb.gcsu.edu/thecorinthian/vol13/iss1/1 1

[3] Brooks, C., \& Warren, R. P. (1958). Modern Rhetoric (2nd ed.). San Diego: Harcourt, Brace And Company.

[4] Lockhart, T. 2012. Emerging Voices: The Shifting Rhetorics of Style: Writing in Action in Modern Rhetoric. The National Council of Teachers of English, 75(1), 16-41.

[5] Craig R, S. 2017. Rhetoric and Human Consciousness (5nd ed.). Cambridge: Waveland Press.

[6] Oxford Dictionary. (2012). Paperback Oxford English Dictionary. Oxford: Oxford University Press. 